\title{
Modulation of pathogen-induced CCL20 secretion from HT-29 human intestinal epithelial cells by commensal bacteria
}

\author{
Shomik Sibartie ${ }^{\dagger}$, Ann M O'Hara ${ }^{\dagger}$, Jude Ryan, Áine Fanning, Jim O'Mahony, \\ Shaun O'Neill, Barbara Sheil, Liam O'Mahony and Fergus Shanahan*
}

Address: Alimentary Pharmabiotic Centre, University College Cork, National University of Ireland, Cork, Ireland

Email: Shomik Sibartie - shomiksibartie@gmail.com; Ann M O'Hara - ann.ohara@nuigalway.ie; Jude Ryan - juderyan@eircom.net; Áine Fanning - ainefanning@yahoo.com; Jim O'Mahony - jim.omahony@cit.ie; Shaun O'Neill - son123@ucc.ie; Barbara Sheil - B.Sheil@ucc.ie; Liam O'Mahony - liam.omahony@siaf.uzh.ch; Fergus Shanahan* f.shanahan@ucc.ie

* Corresponding author †Equal contributors

Published: 8 October 2009

BMC Immunology 2009, 10:54 doi:10.1186/147|-2172-10-54
Received: 3 April 2009

Accepted: 8 October 2009

This article is available from: http://www.biomedcentral.com/I47I-2/72/I0/54

(c) 2009 Sibartie et al; licensee BioMed Central Ltd.

This is an Open Access article distributed under the terms of the Creative Commons Attribution License (http://creativecommons.org/licenses/by/2.0), which permits unrestricted use, distribution, and reproduction in any medium, provided the original work is properly cited.

\begin{abstract}
Background: Human intestinal epithelial cells (IECs) secrete the chemokine CCL20 in response to infection by various enteropathogenic bacteria or exposure to bacterial flagellin. CCL20 recruits immature dendritic cells and lymphocytes to target sites. Here we investigated IEC responses to various pathogenic and commensal bacteria as well as the modulatory effects of commensal bacteria on pathogen-induced CCL20 secretion. HT-29 human IECs were incubated with commensal bacteria (Bifidobacterium infantis or Lactobacillus salivarius), or with Salmonella typhimurium, its flagellin, Clostridium difficile, Mycobacterium paratuberculosis, or Mycobacterium smegmatis for varying times. In some studies, HT-29 cells were pre-treated with a commensal strain for $2 \mathrm{hr}$ prior to infection or flagellin stimulation. CCL20 and interleukin (IL)-8 secretion and nuclear factor (NF)- $\mathrm{kB}$ activation were measured using enzyme-linked immunosorbent assays.
\end{abstract}

Results: Compared to untreated cells, S. typhimurium, C. difficile, M. paratuberculosis, and flagellin activated NF-KB and stimulated significant secretion of CCL20 and IL-8 by HT-29 cells. Conversely, B. infantis, $L$. salivarius or $M$. smegmatis did not activate NF-KB or augment CCL20 or IL-8 production. Treatment with $B$. infantis, but not $L$. salivarius, dose-dependently inhibited the baseline secretion of CCL20. In cells pre-treated with B. infantis, C. difficile-, S. typhimurium-, and flagellininduced CCL20 were significantly attenuated. B. infantis did not limit M. Paratuberculosis-induced CCL20 secretion.

Conclusion: This study is the first to demonstrate that a commensal strain can attenuate CCL20 secretion in HT-29 IECs. Collectively, the data indicate that M. paratuberculosis may mediate mucosal damage and that $B$. infantis can exert immunomodulatory effects on IECs that mediate host responses to flagellin and flagellated enteric pathogens.

\section{Background}

Intestinal epithelial cells (IECs) play a crucial role in the maintenance of mucosal homeostasis, and actively sam- ple commensal bacteria, pathogens, and other antigens $[1,2]$. Under normal circumstances, the mucosal immune system exhibits a restrained response to commensal bac- 
teria whilst retaining an ability to mount appropriate immune responses to pathogenic bacteria. IECs can trigger innate immune responses that activate pro-inflammatory signalling pathways, as well as direct the migration of various effector cells involved in adaptive immunity [2]. Bone marrow-derived dendritic cells (DCs) in the lamina propria also sample commensal and pathogenic bacteria at mucosal interfaces $[3,4]$. This appears to be achieved by opening tight junctions and extending dendrites between IECs [5]. Encounter with bacteria or bacterial antigens triggers the functional maturation of DCs leading to the generation of antigen-presenting cells that can activate naïve T cells [6]. Therefore, the recruitment of DCs into the epithelium is a prerequisite for the initiation of adaptive immune responses.

Trafficking of leukocytes and DCs to a specific site is dependent on chemokines [7]. Chemokines bind to and activate members of $\mathrm{G}$ protein-coupled seven-transmembrane domain receptors that are differentially expressed on leukocytes [8]. The chemokine CCL20 (also known as macrophage inflammatory protein-3 $\alpha$, liver and activated-regulated chemokine, or Exodus-1) selectively attracts effector and memory $\mathrm{T}$ lymphocytes, immature DCs, and naïve $\mathrm{B}$ cells that express its specific receptor, CCR6 [9]. CCL20 is expressed constitutively at immunological barriers such as the gastrointestinal tract and the skin. The colonic epithelium has been demonstrated as a major source of CCL20 and epithelial expression of this chemokine is elevated in inflammatory bowel disease [10]. The appendix, tonsils, and skin keratinocytes are also significant producers of CCL20 [11-13]. CCL20 expression in IECs is increased by a variety of inflammatory stimuli such as interleukin (IL)- $1 \beta$, tumour necrosis factor- $\alpha$, and enteropathogenic bacteria including species of Salmonella and Listeria [14-16]. It has been shown that flagellin, the protein subunit of bacterial flagella, rather than lipopolysaccharide or invasion, is the key Salmonella virulence factor responsible for the induction of epithelial CCL20 [16]. Recent studies found that CCL20 transcription is upregulated by flagellin-Toll-like receptor 5 (TLR5) signaling in the human intestinal epithelial cell lines: T84 and Caco-2 [16,17]. The constitutive and inducible expression of CCL20 implicates an important role for CCL20 both in gut homeostasis and in mucosal immune responses to stress signals. CCL20 expression is upregulated in a variety of inflammatory disorders including appendicitis, atopic dermatitis, rheumatoid arthritis, and inflammatory bowel diseases such as Crohn's disease [9]. This suggests that mucosal inflammation is associated with altered leukocyte and DC trafficking.

Recent evidence supports the role of commensal bacteria in maintaining immune homeostasis within the gut [1820]. Several strains of commensal bacteria can function- ally modulate the epithelium by attenuating the secretion of the neutrophil-recruiting chemokine IL-8 [19-23]. In this study, we examined CCL20 production in response to individual pathogenic and commensal bacteria and whether commensal bacteria could restrain CCL20 secretion specifically from HT-29 IECs. We demonstrate differential stimulation of CCL20 secretion from HT-29 cells and an attenuation of both baseline and inducible CCL20 secretion by commensal bacteria. Collectively, the data could indicate that certain commensal bacteria could contribute to the maintenance of mucosal homeostasis by restraining exaggerated inflammatory responses to the antigenic burden within the gut.

\section{Methods \\ Bacteria and growth conditions}

The commensal strains used in this study, Bifidobacterium infantis 35624 and Lactobacillus salivarius subspecies salivarius UCC118 $[24,25]$, have been shown previously to have probiotic properties $[23,24,26,27]$. The bacteria were stored in $50 \%$ glycerol at $-70^{\circ}$. Prior to use in experiments, $B$. infantis was cultured anaerobically at $37^{\circ}$ in de Man Rogosa Sharpe (MRS) (Merck, Darmstadt, Germany) broth supplemented with $0.05 \%$ cysteine (Sigma-Aldrich, St. Louis, MO) for $48 \mathrm{hr}$, whereas L. salivarius was cultured anaerobically at $37^{\circ}$ in MRS broth for $18 \mathrm{hr}$. The stationary-phase bacteria were centrifuged and were resuspended in sterile phosphate-buffered saline (PBS).

The flagellated enteropathogenic bacteria used in this study were gram-negative Salmonella typhimurium UK1 and gram-positive Clostridium difficile ribotype 001. S. typhimurium UK1 (kindly provided by R. Curtiss III, Washington University in St Louis, MO) was stored in 50\% glycerol at $-70^{\circ}$. For experimental investigations, the bacteria were cultured at $37^{\circ}$ in tryptic soy broth (Merck) for $18 \mathrm{hr}$ under aerobic conditions.

Subsequently, the bacteria were centrifuged and resuspended in PBS. C. difficile 001 (kindly provided by J. Brazier, Anaerobic Reference Laboratory, University Hospital of Wales, Cardiff, UK) is a common cause of nosocomial diarrhoea [28]. It produces exotoxins A and B that are proinflammatory and enterotoxic in the human intestine $[29,30]$. C. difficile was cultured at $37^{\circ}$ under anaerobic conditions in fastidious anaerobic broth (Lab M, International Diagnostics Group Plc, Bury, UK) for $48 \mathrm{hr}$, followed by sub-culturing in fresh fastidious anaerobic broth for a further $24 \mathrm{hr}$. Live C. difficile bacteria present in the culture broth were used directly to infect HT-29 monolayers.

Subsequently, cell-free supernatants were harvested by centrifugation at $2500 \mathrm{~g}$ for $10 \mathrm{~min}$. The supernatant was carefully decanted through a $0.2 \mu \mathrm{m}$ filter to remove any 
residual bacteria. The absence of viable bacterial cells in the cell-free supernatant was confirmed by plating aliquots of the cell-free supernatant onto Columbia blood agar (Oxoid, Hampshire, UK).

Mycobacterium avium subspecies paratuberculosis ATCC43109 (American Type Culture Collection, Manassas, VA) was cultured in Middlebrook 7H9 broth (Difco Laboratories, Detroit, MI) supplemented with 10\% Middlebrook oleic acid/albumin/dextrose/catalase (OADC) (Becton Dickinson, Franklin Lakes, NJ), 2 ml/1 80\% glycerol and $2 \mathrm{mg} / \mathrm{ml}$ mycobactin J (Allied Laboratories Inc., Synbiotics Europe) for 2 weeks at $37^{\circ}$ in a shaking aerobic incubator. Subsequently, the bacteria were subcultured for a further month in Middlebrook 7H9 broth supplemented with OADC and mycobactin J. Mycobacterium smegmatis mc(2) 155 (University College Cork Culture Collection), a non-pathogenic mycobacteria that has been used frequently as a tool in the study of mycobacterial genetics [31], was grown similarly but without the addition of mycobactin J. Prior to use, the mycobacteria were centrifuged and resuspended in PBS. The viability of the mycobacteria cultures was tested routinely using ZiehlNielssen acid-fast staining and culture purity was assessed by streaking serial dilutions of the bacterial suspensions on tryptic soy agar (TSA) (Merck). The appearance of any colonies following $24 \mathrm{hr}$ incubation at $37^{\circ}$ indicated contamination.

For all assays, bacteria were used in the stationary-phase of growth and were Gram-stained or streaked on TSA (for mycobacteria species) to confirm purity. Bacterial number was estimated by measuring the absorbance at $600 \mathrm{~nm}$, and relating the absorbance value to a standard curve of colony forming units (CFU) on MRS agar (Merck) (for $B$. infantis and L. salivarius), TSA (for S. typhimurium), Columbia blood agar (for C. difficile), or Middlebrook agar (for M. paratuberculosis and M. smegmatis).

\section{Epithelial cell culture}

In this study, the HT-29 human colonic epithelial cell line (American Type Culture Collection) was chosen because this IEC has been used extensively by us and other groups investigating epithelial responses to bacteria [2123,32,33]. HT-29 cells were cultured in modified McCoy's 5A medium (GIBCO-BRL, Grand Island, NY) supplemented with $10 \%$ heat-inactivated fetal calf serum (FCS) (Sigma) in the presence or absence of $100 \mathrm{U} / \mathrm{ml}$ penicillin $\mathrm{G}$ and $100 \mu \mathrm{g} / \mathrm{ml}$ streptomycin (GIBCO-BRL). The cells were routinely propagated in $75-\mathrm{cm} 2$ tissue culture flasks at $37^{\circ}$ in a humidified, $5 \% \mathrm{CO}_{2}$ incubator until they approached $80-90 \%$ confluency. Subsequently, the cells were trypsinized and used in experimental investigations as specified below.

\section{HT-29 cell treatments}

For all assays, cell viability was determined by trypan blue exclusion, and a known number of HT-29 cells were seeded into $3.8-\mathrm{cm}^{2} 12$-well plates and grown to confluence. Time and dose response studies were carried out as part of the optimisation phase of this study (data not shown). HT-29 cell-viability and $\mathrm{pH}$ changes were also taken into account. Hence, for experiments, S. typhimurium was used at $1 \times 10^{7} \mathrm{CFU} / \mathrm{ml}$ (MOI 10) for $6 \mathrm{hr}$ given optimal secretion of chemokines within this time. $M$. paratuberculosis and $M$. smegmatis were used at $1 \times 10^{7}$ $\mathrm{CFU} / \mathrm{ml}$ or $1 \times 10^{8} \mathrm{CFU} / \mathrm{ml}$ (MOI 10 and 100 respectively) for $6 \mathrm{hr}$ and $12 \mathrm{hr}$. A longer incubation period resulted in impaired cell viability. C. difficile was used at $1 \times 10^{7} \mathrm{CFU} /$ $\mathrm{ml}$ (MOI 10) for up to $24 \mathrm{hr}$. Confluent monolayers were also treated with $1 \times 10^{5}, 1 \times 10^{6}$, or $1 \times 10^{7} \mathrm{CFU} / \mathrm{ml}$ live commensal bacteria B. infantis or L. Salivarius for $6 \mathrm{hr}$. Formalin-killed commensal bacteria, prepared as described previously [34], were used to treat confluent HT-29 monolayers at a dose equivalent to $1 \times 10^{7} \mathrm{CFU} / \mathrm{ml}$. Dose response studies were performed to determine the optimal concentration of flagellin to use for stimulation of IECs. Subsequently, HT-29 cells were treated with $0.5 \mu \mathrm{g} /$ $\mathrm{ml}$ purified $S$. typhimurium flagellin (InvivoGen Corp., San Diego, CA), a dose used by us in a previous study [23]. In some experiments, HT-29 cells were pre-treated for $2 \mathrm{hr}$ with or without a known dose of commensal bacteria. Subsequently, the cells were incubated under aerobic conditions with an equivalent dose of S. typhimurium, C. difficile culture, an equivalent volume of $C$. difficile cell-free supernatant, or with $1 \times 10^{8} \mathrm{CFU} / \mathrm{ml}$ mycobacteria, or were treated with $0.5 \mu \mathrm{g} / \mathrm{ml}$ flagellin for varying times. Modified McCoy's 5A medium supplemented with $10 \%$ heat-inactivated fetal calf serum and $100 \mathrm{U} / \mathrm{ml}$ penicillin $\mathrm{G}$ and $100 \mu \mathrm{g} / \mathrm{ml}$ streptomycin was used. Antibiotics were useful in preventing contamination and maintaining a bacteriostatic effect. The concentration $\left(1 \times 10^{7} \mathrm{CFU} / \mathrm{ml}\right)$ of S. typhimurium and C. difficile at the end-point of the coculture system was determined by streaking appropriate agar plates. No bacterial growths, $\mathrm{pH}$ changes or impaired cell-viability were recorded.

\section{CCL20 Enzyme-linked immunosorbent assay}

Confluent HT-29 cells grown in antibiotic- and serumsupplemented media were treated for varying times with known doses of bacteria or flagellin. Following treatment, immunoreactive CCL20 protein levels in cell-culture supernatants were quantified using an enzyme-linked immunosorbent assay (ELISA) DuoSet kit (R\&D Systems, Minneapolis, $\mathrm{MN}$ ) according to the manufacturer's protocol.

\section{IL-8 ELISA}

Immunoreactive IL-8 protein levels in cell-culture supernatants of bacteria- or flagellin-treated HT-29 cells were 
quantified using an ELISA DuoSet kit (R\&D Systems) according to the manufacturer's protocol.

\section{Nuclear factor (NF)-кB p65 transcription factor assay}

Confluent HT-29 monolayers were treated for $1 \mathrm{hr}$ with known doses of bacteria or flagellin. Nuclear proteins were extracted using the Active Motif Nuclear Extract kit (Active Motif Europe, Rixensart, Belgium) according to the manufacturer's instructions, and the total protein concentration of the lysates was determined by Bradford assay (Bio-Rad, Hercules, CA). Activation of the nuclear factor

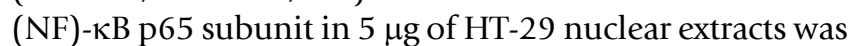
determined using an NF- $\kappa \mathrm{B}$ p65 ELISA-based transcription factor assay kit (TransAM assay) (Active Motif Europe) according to the manufacturer's protocol. The $\mathrm{NF}-\kappa \mathrm{B}$ detecting antibody recognizes an epitope on p65 that is accessible only when NF- $\kappa \mathrm{B}$ is activated. The positive control Jurkat nuclear extract provided with the kit was used to assess assay specificity.

\section{Statistics}

All data are expressed as mean \pm SE. Statistical analyses were performed using unpaired two-tailed Student's $t$ tests or analysis of variance (ANOVA). $P$ values $<0.05$ were considered to be statistically significant, and $n$ represents the number of independent experiments performed.

\section{Results \\ HT-29 IECs respond differentially to commensal and pathogenic bacteria}

ELISA was used to examine CCL20 and IL-8 protein secretion from confluent HT-29 monolayers treated for 6 hr, 12 hr or 24 hr. HT-29 cells constitutively secreted CCL20, and $119.5( \pm 26) \mathrm{pg} / \mathrm{ml}$ CCL20 were detected in cell culture supernatants from untreated cells after $6 \mathrm{hr}$ (Fig. 1). Compared to untreated cells, infection with S. typhimurium (1 $\times 10^{7} \mathrm{CFU} / \mathrm{ml}$ ) or exposure to its flagellin stimulated significant secretion of CCL20 within $6 \mathrm{hr}$. The levels of CCL20 induced by $S$. typhimurium or flagellin were comparable. C. Difficile significantly stimulated CCL20 secretion only after $24 \mathrm{hr}$ incubation. (Fig. 1). The levels of CCL20 induced by $C$. difficile bacteria $\left(1 \times 10^{7} \mathrm{CFU} / \mathrm{ml}\right)$ $(1102 \pm(64) \mathrm{pg} / \mathrm{ml})$ and their cell-free supernatants $(1232 \pm(67) \mathrm{pg} / \mathrm{ml})$ were similar. Dose and time response studies indicated that at a dose of $1 \times 10^{8} \mathrm{CFU} /$ $\mathrm{ml}$ M. paratuberculosis stimulated significant secretion of CCL20 following $12 \mathrm{hr}$ of infection. M. paratuberculosis did not induce CCL20 release at lower doses or at earlier time-points, and M. smegmatis did not stimulate CCL20 secretion at any of the doses or time-points tested. Moreover, the commensal bacteria $\left(1 \times 10^{7} \mathrm{CFU} / \mathrm{ml}\right)$ did not induce CCL20 release at any time-point tested (Fig. 1).

Previously, we have shown that flagellin and S. typhimurium, but not $B$. Infantis or $L$. salivarius, significantly induce IL-8 protein secretion from HT-29 cells [23]. In the current study, we examined whether $C$. difficile and the mycobacteria species used here stimulate IL- 8 secretion from HT-29 IECs. As shown in Fig. 2, infection with C. difficile bacteria and their cell-free supernatants significantly stimulated IL- 8 protein secretion after $24 \mathrm{hr}$ incubation but not at earlier time points. Exposure to $1 \times 10^{8} \mathrm{CFU} / \mathrm{ml}$ M. paratuberculosis, but not M. smegmatis, significantly stimulated IL-8 protein secretion after $12 \mathrm{hr}$ compared to untreated cells (2.78-fold increase). No significant IL-8 secretion was recorded at earlier time points and at lower doses of M. paratuberculosis or M. smegmatis.

\section{Bacterial-induced NF- KB DNA binding activity in HT-29 IECs}

Both CCL20 and IL-8 are transcriptionally regulated by the transcription factor NF- $\kappa \mathrm{B}[35,36]$. In view of our finding that HT-29 IECs respond differentially to various bacteria, and in particular, that $M$. paratuberculosis triggers CCL20 and IL- 8 secretion, we next examined NF- $\kappa$ B activation in bacterial-treated HT-29 cells. Exposure of HT-29 cells for $1 \mathrm{hr}$ to $S$. typhimurium $\left(1 \times 10^{7} \mathrm{CFU} / \mathrm{ml}\right)$, flagellin $(0.5 \mu \mathrm{g} / \mathrm{ml})$, C. difficile $\left(1 \times 10^{7} \mathrm{CFU} / \mathrm{ml}\right)$, or M. paratuberculosis $\left(1 \times 10^{7}\right.$ or $\left.1 \times 10^{8} \mathrm{CFU} / \mathrm{ml}\right)$ augmented the DNA binding activity of the p65 subunit of NF- $\kappa \mathrm{B}$ compared with untreated cells (Fig. 3). Although the levels of activated NF- $\mathrm{B}$ detected in C. difficile and M. paratuberculosisinfected cells were less than those detected in S. typhimurium infected cells, they were significant nonetheless. NF$\kappa \mathrm{B}$ DNA binding activity was detected in the positive control Jurkat nuclear extract, and the specificity of the NF- $\kappa$ B binding in the assay was confirmed by competition with free wild-type $\mathrm{NF}-\kappa \mathrm{B}$ consensus oligonucleotide or mutated NF- $\kappa$ B oligonucleotide (Fig. 3). Together the data demonstrate that HT-29 IECs respond differentially to various antigens and, although $M$. paratuberculosis is not as potent an immune activator as $S$. typhimurium, these mycobacteria do trigger inflammatory responses.

\section{B. infantis inhibits CCL20 secretion at baseline}

In view of our previous finding that commensal bacteria attenuate IL-8 secretion at baseline [23], we examined whether treatment with increasing doses of $B$. infantis or L. salivarius $\left(1 \times 10^{5}, 1 \times 10^{6}\right.$, or $\left.1 \times 10^{7} \mathrm{CFU} / \mathrm{ml}\right)$ affected the baseline secretion of CCL20 by confluent HT-29 monolayers. CCL20 protein levels were measured after $6 \mathrm{hr}$. In cells treated with $B$. infantis, a dose-dependent inhibition of baseline CCL20 secretion by confluent HT-29 monolayers was observed (Fig. 4a). At a dose of $1 \times 10^{7} \mathrm{CFU} / \mathrm{ml}$, which under the experimental conditions was equivalent to approximately 10 bacteria per epithelial cell, B. infantis significantly inhibited basal CCL20 secretion by $24 \%$. Conversely, treatment with $L$. salivarius did not attenuate baseline CCL20 secretion at any dose tested. 


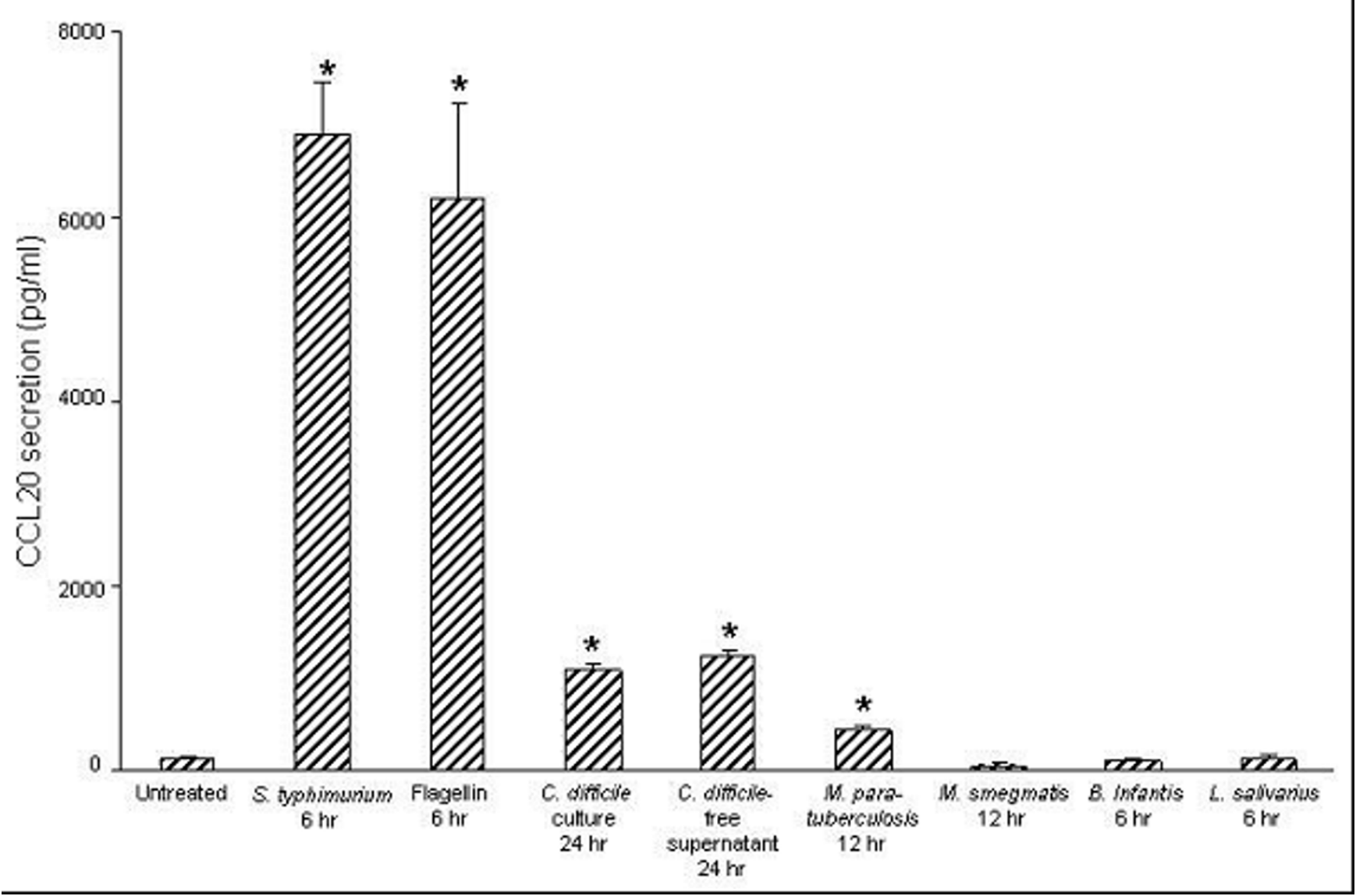

\section{Figure I}

Intestinal epithelial cells secrete CCL20 differentially in response to various bacteria. Confluent $\mathrm{HT}-29$ cells were treated with Salmonella typhimurium ( $\mathrm{I} \times 10^{7}$ colony-forming units $\left.(\mathrm{CFU}) / \mathrm{ml}\right)$, flagellin $(0.5 \mu \mathrm{g} / \mathrm{ml})$, Clostridium difficile $\left(\mathrm{I} \times 10^{7}\right.$ $\mathrm{CFU} / \mathrm{ml})$, an equal volume of their cell-free culture supernatants, Mycobacterium paratuberculosis $\left(\mathrm{I} \times 10^{8} \mathrm{CFU} / \mathrm{ml}\right), \mathrm{M}$. smegmatis $\left(\mathrm{I} \times 10^{8} \mathrm{CFU} / \mathrm{ml}\right)$, Bifidobacterium infantis $\left(\mathrm{I} \times 10^{7} \mathrm{CFU} / \mathrm{ml}\right)$, or Lactobacillus salivarius $\left(\mathrm{I} \times 10^{7} \mathrm{CFU} / \mathrm{ml}\right)$. CCL20 protein levels in cell culture supernatants were measured after $6 \mathrm{hr}, 12 \mathrm{hr}$, or $24 \mathrm{hr}$ as specified on the above graph. Significant levels of CCL20 were only detected after $12 \mathrm{hr}$ incubation with $M$. paratuberculosis and after $24 \mathrm{hr}$ with $C$. difficile. M. smegmatis, B. Infantis and $L$. Salivarius did not result in significant CCL20 secretion at any of the time points or concentrations used. The data are expressed as $\mathrm{pg} / \mathrm{ml} \mathrm{CCL20}$ and represent the mean \pm standard error $(n=7$ independent experiments). $* p<0.05$ relative to untreated cells.

In order to determine whether the attenuation of constitutive CCL20 production was dependent on live B. infantis, we examined the effect of formalin-killed bacteria on CCL20 protein levels. Similar to live $B$. infantis, at a dose equivalent to $1 \times 10^{7} \mathrm{CFU} / \mathrm{ml}$ formalin-killed $B$. infantis significantly inhibited the baseline secretion of CCL20 (Fig. 4b). In contrast, neither live nor formalin-killed $L$. salivarius affected the constitutive secretion of CCL20. Together these data demonstrate that the ability of commensal bacteria to restrain the baseline secretion of CCL20 is species-specific and does not require live bacteria.

\section{B. infantis attenuates CCL20 induction by flagellated pathogenic bacteria}

As shown in Fig. 5(a), infection of HT-29 monolayers with S. typhimurium induced $8006 \pm(1140) \mathrm{pg} / \mathrm{ml}$ CCL20 after 6 hr. Pre-treatment with live B. infantis limited S. typhimurium-induced CCL20 secretion $(P=0.059)$, and pre-treatment with formalin-killed $B$. infantis significantly attenuated S. typhimurium-induced CCL20 production. The modulation of S. typhimurium-stimulated CCL20 production by commensal bacteria was strain-specific; $L$. salivarius did not dampen the IEC CCL20 response to $S$. typhimurium. 


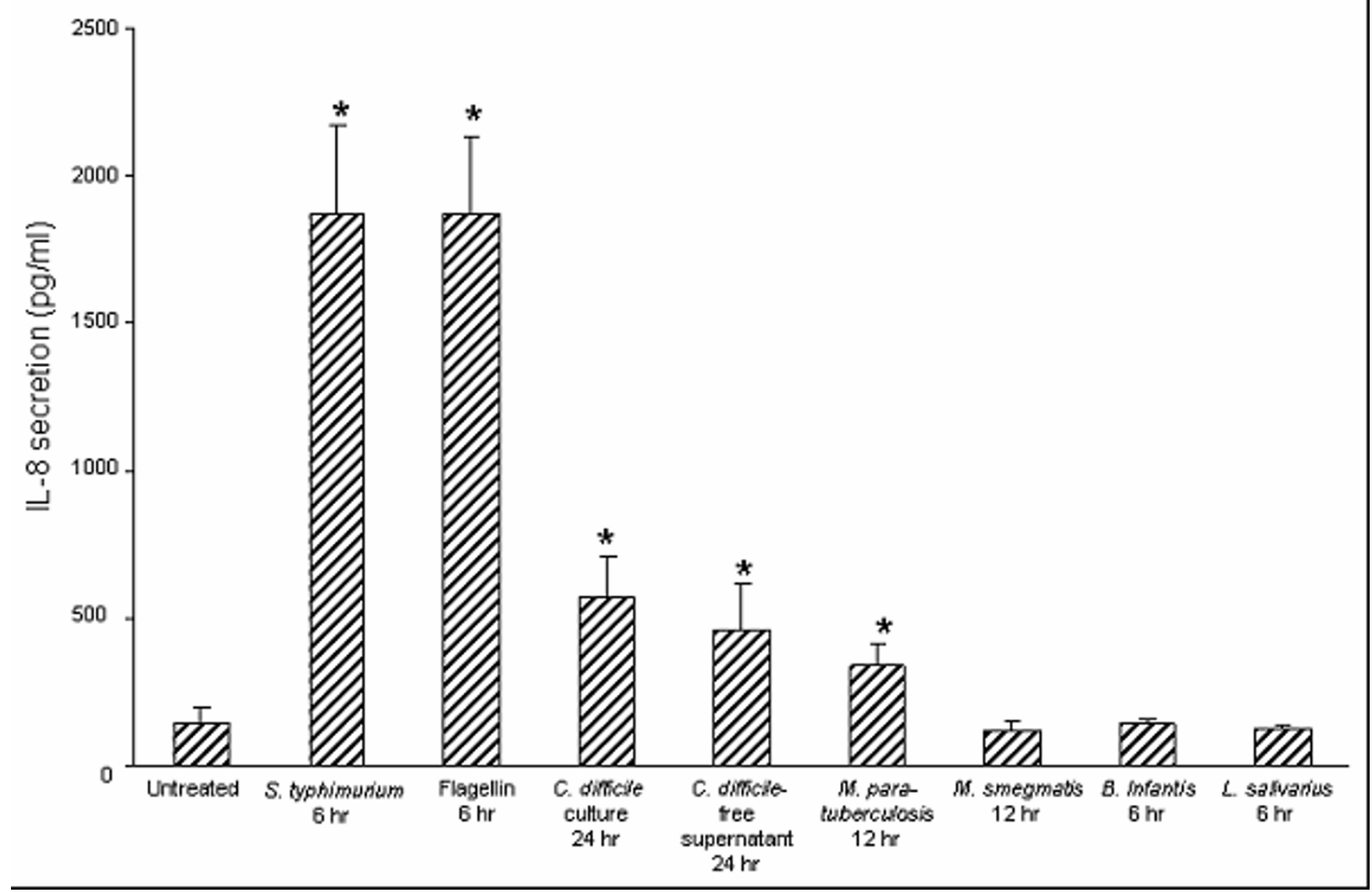

\section{Figure 2}

Intestinal epithelial cells secrete interleukin (IL)-8 differentially in response to various bacteria. Confluent HT-29 cells were treated with Salmonella typhimurium (I $\times 10^{7}$ colony-forming units (CFU)/ml), flagellin $(0.5 \mu \mathrm{g} / \mathrm{ml})$, Clostridium difficile $\left(\mathrm{I} \times 10^{7} \mathrm{CFU} / \mathrm{ml}\right)$, an equal volume of their cell-free culture supernatants, Mycobacterium paratuberculosis $\left(\mathrm{I} \times 10^{8} \mathrm{CFU} / \mathrm{ml}\right), \mathrm{M}$. smegmatis $\left(\mathrm{I} \times 10^{8} \mathrm{CFU} / \mathrm{ml}\right)$, Bifidobacterium infantis $\left(\mathrm{I} \times 10^{7} \mathrm{CFU} / \mathrm{ml}\right)$, or Lactobacillus salivarius $\left(\mathrm{I} \times 10^{7} \mathrm{CFU} / \mathrm{ml}\right)$. IL-8 protein levels in cell culture supernatants were measured after $6 \mathrm{hr}, 12 \mathrm{hr}$, or $24 \mathrm{hr}$ as specified by enzyme-linked immunosorbent assay. The data are expressed as $\mathrm{pg} / \mathrm{ml} \mathrm{IL-8}$ and represent the mean \pm standard error $(n=7$ independent experiments). $* P<$ 0.05 relative to untreated cells.

Considering that flagellin has been shown to be the key Salmonella virulence factor responsible for the induction of epithelial CCL20 [16], we next examined whether $B$. infantis could inhibit IEC responses to Salmonella flagellin. Confluent HT-29 monolayers were pre-treated with $B$. infantis $\left(1 \times 10^{5}, 1 \times 10^{6}\right.$, or $\left.1 \times 10^{7} \mathrm{CFU} / \mathrm{ml}\right)$ for $2 \mathrm{hr}$, followed by $0.5 \mu \mathrm{g} / \mathrm{ml}$ flagellin for $6 \mathrm{hr}$. Pre-treatment with B. infantis inhibited flagellin-induced CCL20 secretion in a dose-dependent manner. At a dose of $1 \times 10^{7} \mathrm{CFU} / \mathrm{ml} B$. infantis this inhibition was significant and was not dependent on the presence of live bacteria (Fig. 5b).

We next sought to determine whether $B$. infantis could limit CCL20 induction by pathogenic bacteria other than
Salmonella. To address this question, we used flagellated C. difficile and non-flagellated M. paratuberculosis. HT-29 monolayers were pre-treated with live B. infantis or L. salivarius for $2 \mathrm{hr}$, followed by treatment with M. paratuberculosis for $12 \mathrm{hr}$ or with C. difficile for $24 \mathrm{hr}$. Pre-treatment with $B$. infantis, but not $L$. salivarius, significantly attenuated CCL20 release in response to both C. difficile bacteria and their cell-free supernatants by $33.4 \%$ or $26.7 \%$, respectively (Fig. 6). In contrast, pre-treatment with the bifidobacteria did not modulate $M$. paratuberculosis induced CCL20 secretion. Collectively, the data indicate that $B$. infantis can restrain CCL20 secretion in response to flagellin as well as to gram-negative and gram-positive 


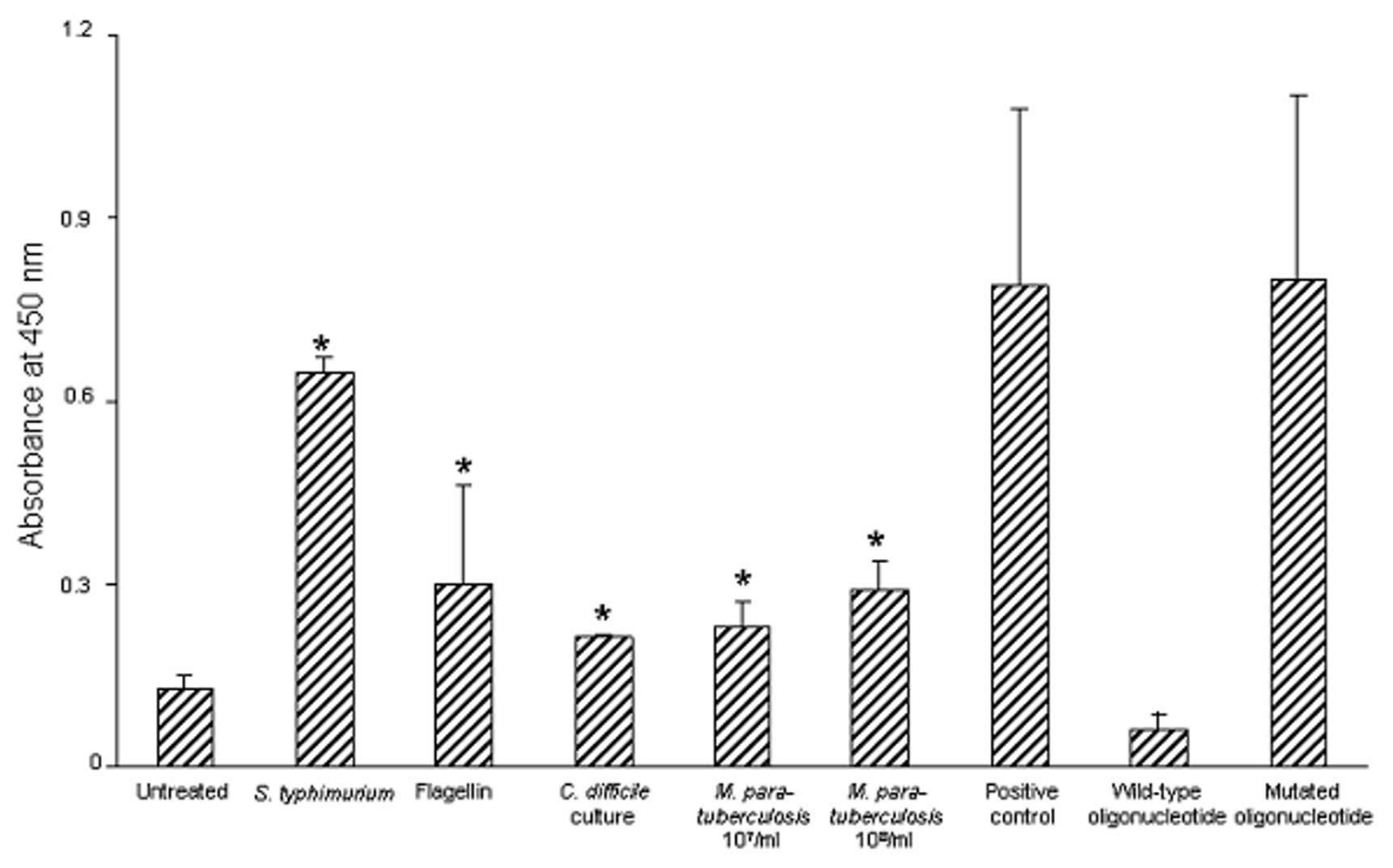

Figure 3

Bacterial-induced NF-kB DNA binding activity in intestinal epithelial cells. HT-29 cells were untreated, or were exposed to Salmonella typhimurium $\left(\mathrm{I} \times 10^{7}\right.$ colony forming units $\left.(\mathrm{CFU}) / \mathrm{ml}\right)$, flagellin $(0.5 \mu \mathrm{g} / \mathrm{ml})$, Clostridium difficile $\left(\mathrm{I} \times 10^{7}\right.$ $\mathrm{CFU} / \mathrm{ml})$, or Mycobacterium paratuberculosis $\left(\mathrm{I} \times 10^{7}\right.$ or $\left.\mathrm{I} \times 10^{8} \mathrm{CFU} / \mathrm{ml}\right)$ for I hr. The DNA binding activity of NF- $\mathrm{KB} \mathrm{p} 65$ in HT-29 nuclear extracts was determined using an enzyme-linked immunosorbent assay-based transcription factor assay. The positive control Jurkat nuclear extract provided with the kit was used to verify assay specificity in competition assays with wildtype or mutated NF-kB oligonucleotides. The data represent the mean absorbance readings \pm standard error of five separate experiments. $P<0.05$ relative to untreated cells.

flagellated pathogenic bacteria but not to intracellular non-flagellated bacteria.

\section{Discussion}

In the current study, we have demonstrated that HT-29 IECs secrete CCL20 selectively when exposed to various bacterial species. We show that HT-29 IECs release CCL20 in response to C. difficile, S. typhimurium, M. paratuberculosis, or bacterial flagellin, but not to B. infantis,

L. salivarius, or M. smegmatis. This study is the first to demonstrate that a commensal strain can attenuate CCL20 secretion at baseline as well as the levels of CCL20 released following exposure to flagellin and flagellated enteropathogenic bacteria. To our knowledge, the present study provides the first evidence that $M$. paratuberculosis can induce the secretion of chemokines and activate NF$\kappa \mathrm{B}$ in HT-29 human IECs. Taken together these data suggest that $M$. paratuberculosis is potentially pathogenic and indicate that $B$. infantis can modulate immune responses to flagellin and flagellated pathogenic bacteria.

C. difficile and their toxin-containing supernatants have been shown to stimulate IL-8 production from IECs [37]. However, C. difficile-induced CCL20 secretion has not been reported previously. Our finding that HT-29 IECs secrete comparable amounts of CCL20 in response to both $C$. difficile bacteria and their supernatants indicates that components of the supernatant are responsible for the CCL20 release. Flagellin shed from C. difficile may be the antigenic factor in the supernatant that elicits the secretion of CCL20. However, the supernatant represents 


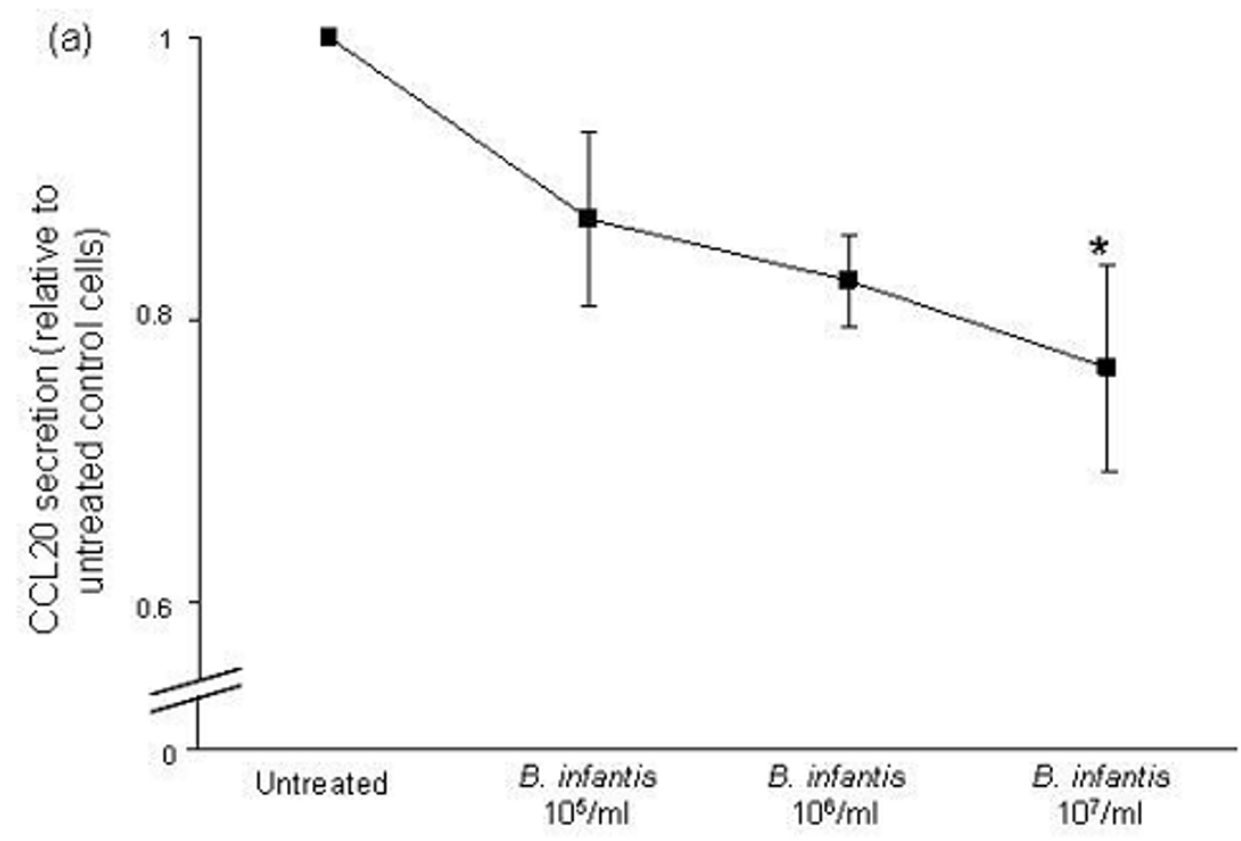

(b)

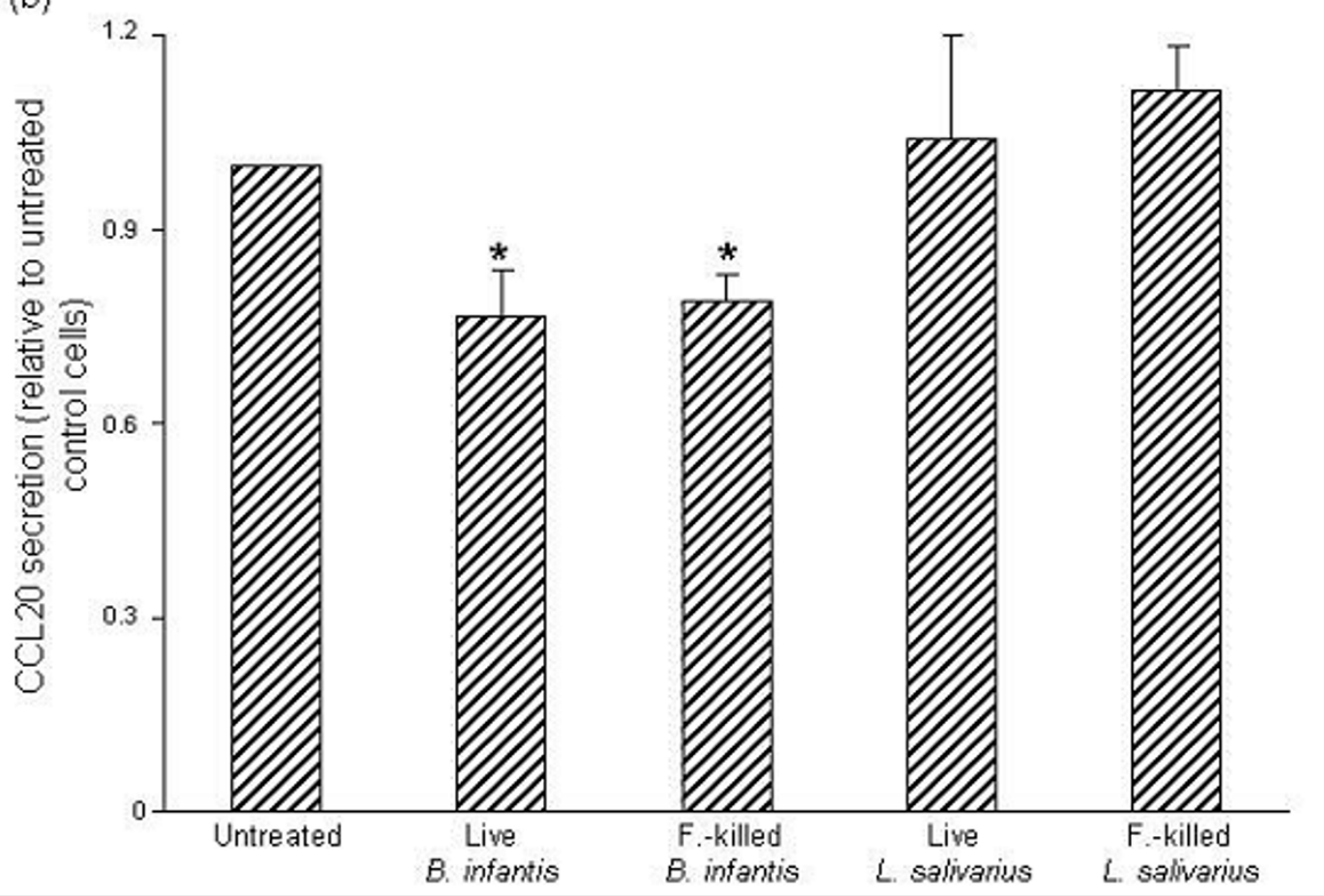

\section{Figure 4}

Bifidobacterium infantis attenuates the baseline secretion of CCL20 in HT-29 cells. (a) Confluent HT-29 monolayers were treated with $B$. infantis at doses of $\mathrm{I} \times 10^{5}$, I $\times 10^{6}$, or $\mathrm{I} \times 10^{7}$ colony-forming units/ml, and CCL20 levels were measured after $6 \mathrm{hr}$. B. infantis caused a dose-dependent inhibition of baseline CCL20 secretion by confluent HT-29 monolayers. (b) Confluent HT-29 cells were treated with I $\times 10^{7} / \mathrm{ml}$ live $B$. infantis or L. salivarius, or an equivalent dose of formalin-killed bacteria. CCL20 levels were measured after $6 \mathrm{hr}$. Both live and formalin-killed $B$. infantis, but not $L$. salivarius, restrained the baseline secretion of CCL20 by HT-29 cells. The data are expressed as CCL20 protein levels relative to untreated control cells and represent the mean \pm standard error ( $n=5$ independent experiments). $* p<0.05$ compared with untreated monolayers. 


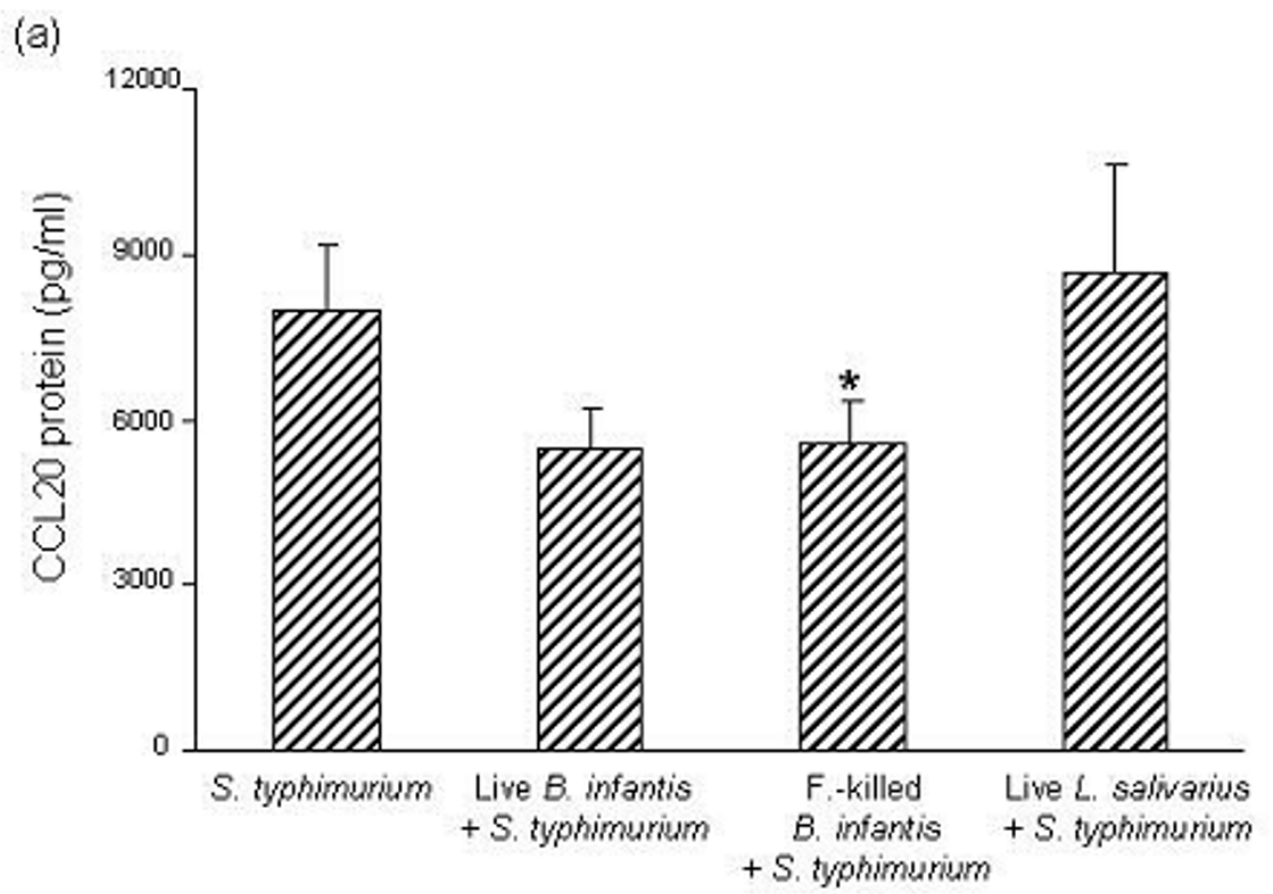

(b)
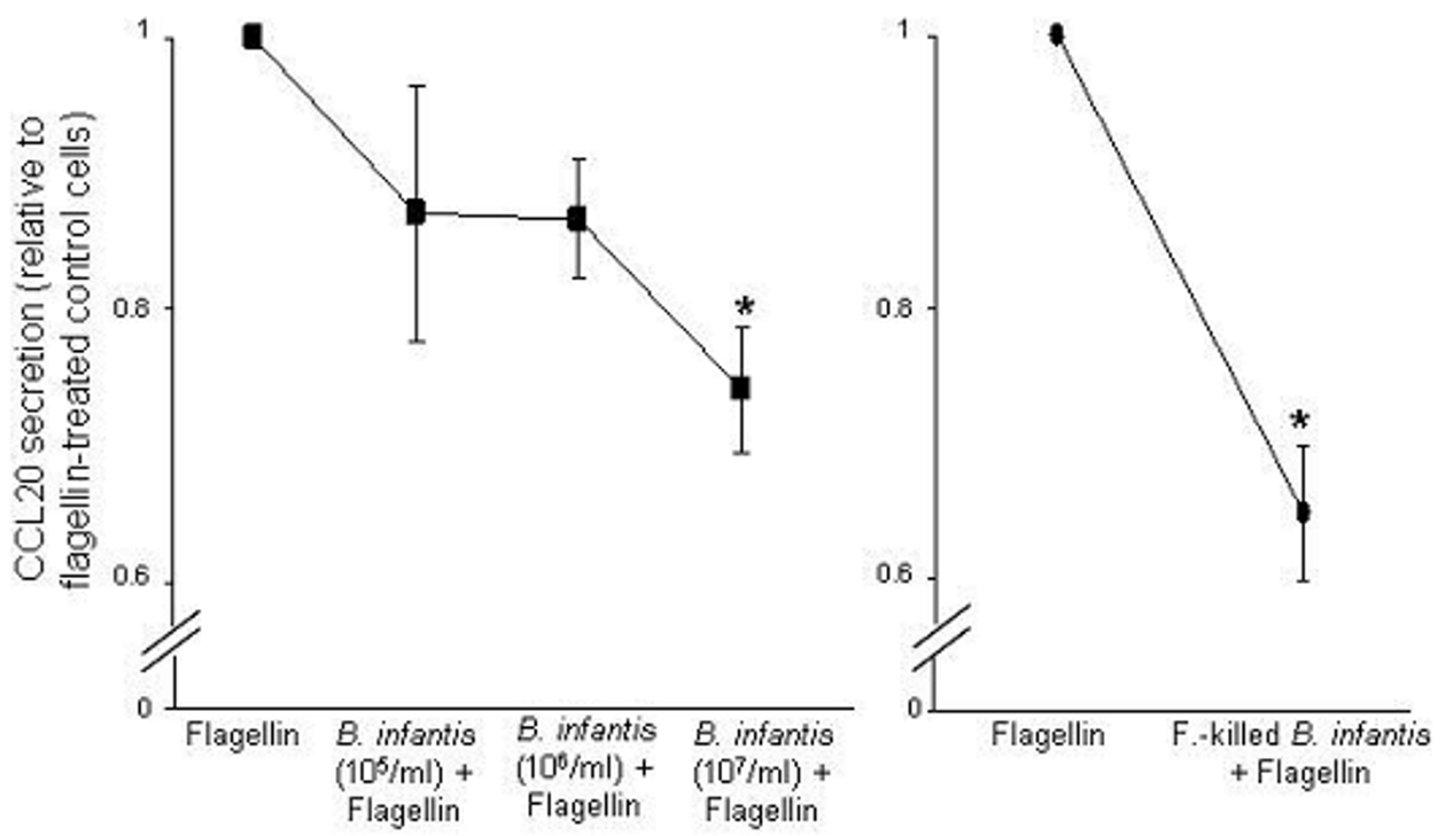

Figure 5 (see legend on next page) 
Figure 5 (see previous page)

Bifidobacterium infantis limits Salmonella typhimurium- and flagellin-induced CCL20 secretion. (a) Confluent HT29 monolayers were pre-treated for $2 \mathrm{hr}$ with $\mathrm{I} \times 10^{7} / \mathrm{ml}$ live $B$. infantis or Lactobacillus salivarius, or an equivalent dose of formalin-killed $B$. infantis prior to infection with S. typhimurium. CCL20 levels were measured $6 \mathrm{hr}$ after infection. Both live and formalin-killed $B$. infantis restrained S. typhimurium induced CCL20 secretion ( $* P<0.05$ compared with $S$. typhimurium-infected HT29 cells). The data are expressed as $\mathrm{pg} / \mathrm{ml}$ CCL20 protein and represent the mean \pm standard error ( $n=8$ independent experiments). (b) Confluent HT-29 monolayers were pre-treated for $2 \mathrm{hr}$ with live B. infantis at doses of $\mathrm{I} \times 10^{5}$, I $\times 10^{6}$, or $\mathrm{I} \times 10^{7}$ colony-forming units $/ \mathrm{ml}$ (left panel) or $\mathrm{I} \times 10^{7} / \mathrm{ml}$ formalin-killed $B$. infantis (right panel). Subsequently, cells were treated with $0.5 \mu \mathrm{g} / \mathrm{ml}$ flagellin for $6 \mathrm{hr}$. Pre-treatment with $\mathrm{I} \times 10^{7}$ live and formalin-killed significantly inhibited flagellin-induced CCL20 secretion $(* P<0.05$ relative to flagellin-treated HT-29 cells). The data are expressed as CCL20 protein levels relative to flagellin-treated cells and represent the mean \pm standard error $(n=7$ independent experiments).

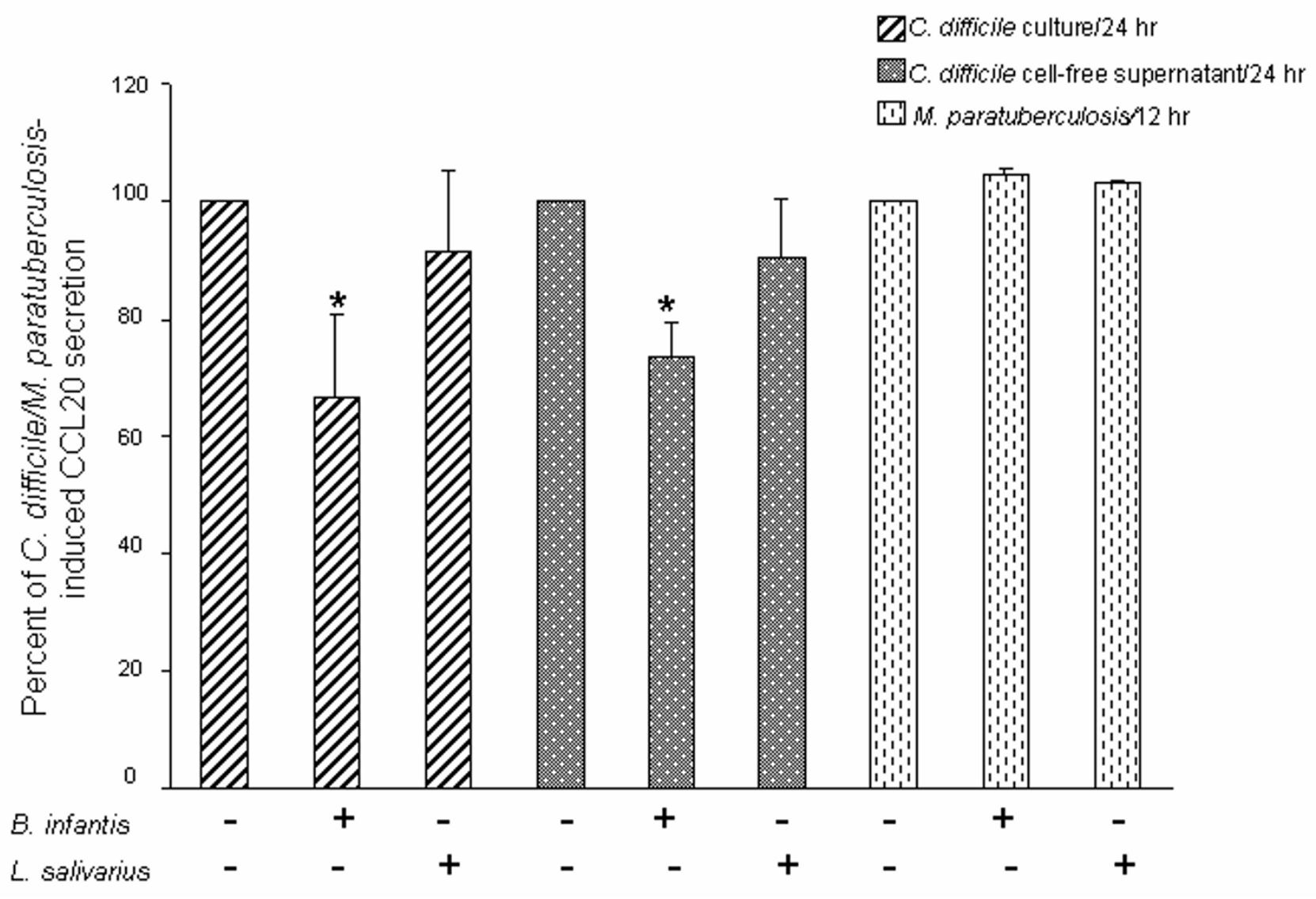

Figure 6

Bifidobacterium infantis attenuates Clostridium difficile-induced CCL20 secretion. Confluent HT-29 monolayers were pre-treated for $2 \mathrm{hr}$ with $\mathrm{I} \times 10^{7}$ colony-forming units $/ \mathrm{ml}(\mathrm{CFU} / \mathrm{ml})$ live $B$. infantis or Lactobacillus salivarius prior to infection with I $\times 10^{7} \mathrm{CFU} / \mathrm{ml} \mathrm{C}$. difficile bacteria or an equal volume of their cell-free supernatants, or I $\times 10^{8} \mathrm{CFU} / \mathrm{ml} \mathrm{Mycobacte-}$ rium paratuberculosis. CCL20 levels were measured $12 \mathrm{hr}$ or $24 \mathrm{hr}$ post-treatment as indicated. $B$. infantis, but not $L$. salivarius, restrained $C$. difficile-induced $C C L 20$ secretion ( $* P<0.05$ compared with $C$. difficile- treated HT-29 cells). $B$. infantis did not limit M. paratuberculosis-induced CCL20 secretion. The data are expressed as per cent of pathogen-induced CCL20 secretion and represent the mean \pm standard error ( $n=6$ independent experiments). 
a crude mixture, and the involvement of other components such as exotoxins A or B cannot be excluded. Nevertheless, flagellin from Salmonella has been shown specifically to stimulate CCL20 secretion by IECs [16]. This leads to the recruitment of CCR6-expressing immature DCs followed by the uptake of flagellated bacteria and subsequent antigen presentation which initiate adaptive immune responses in the gut. TLR 5 activation by flagellin has been shown to stimulate epithelial production of CCL20 and other chemokines like IL-8 $[16,17,38]$. Flagellin-TLR5 signaling stimulates NF- $\mathrm{BB}$ activation to promote CCL20 expression in models of human intestinal epithelial cells [39]. We assume that this mechanism is also responsible for CCL20 expression in our experiments. Recently Muc1 a secreted and membrane bound mucin protein was shown to serve as a receptor that bound Pseudomonas aeruginosa and its flagellin, leading to activation of the MAPK pathway [40]. Muc1 is found in abundance in HT-29 cells but further examination is warranted in regards to its role in NF-kB and MAPK signalling [41].

We demonstrate here that $B$. infantis or $L$. salivarius do not elicit CCL20 protein secretion from HT-29 IECs. This extends our previous finding that IECs display immunological quiescence when exposed to these commensal bacteria [23]. In agreement, it has been shown that other commensal bacteria including Bifidobacterium bifidum, Bacteroides vulgatus, and Lactobacillus reuteri are unable to induce CCL20 mRNA expression in IECs $[16,42]$. However, Lactobacillus rhamnosus can augment CCL20 mRNA and protein expression in human macrophages, but not in rat uterine epithelial cells [10,43]. Recently, Lactobacillus rhamnosus GG (LGG) and Lactobacillus casei have been shown not to induce CCL20 or IL-8 from Caco- 2 cells. In addition, LGG significantly suppressed the expressions of CCL20 induced by a non-pathogenic flagellated Escherichia coli or flagellin when cultured simultaneously [44]. These results are conflicting to our data but reinforce our belief that different strains from the same bacterial species can differ in their molecular interactions with the host.

The mechanism by which $B$. infantis attenuates CCL20 secretion remains to be investigated. CCL20 has been shown to act as an anti-bacterial agent secreted apically as well as basolaterally from IECs. Both secretion apically and basolaterally can be upregulated in response to a number of ligands including muramyl dipeptide, a NOD2 ligand [45]. To survive B. infantis could bind or degrade CCL20. The fact that similar effects are observed using dead $B$. infantis renders this hypothesis less likely and we previously demonstrated that only $10 \%$ of $B$. infantis remain alive after $2 \mathrm{hr}$ in experimental conditions out- lined above [23]. The effects of recombinant CCL20 on B. infantis survival should be assessed.

Another mechanistic explanation would be the downregulation of expression of TLR5 or associated molecules in the TLR5 pathway by $B$. infantis. Detailed characterization of the TLR5 pathway for example using RNA interference of TLR5 or downstream MyD88 is warranted and could demonstrate separate pathways of CCL20 induction for $S$. typhimurium and M. paratuberculosis.

It could be argued that the suppression of CCL20 by commensal strains could predispose to a suboptimal inflammatory response needed for host defence, especially in the compromised host. The antibacterial properties of CCL20 on pathogens and commensals alike should also be considered. B infantis could negate the beneficial antibacterial properties of CCL20. From our previous observations, $B$ infantis, L. Salivarius and S. typhimurium do not survive after $6 \mathrm{hr}$ of incubation in experimental conditions outlined in our study [23]. Hence we believe that $B$. infantis could have more beneficial anti-inflammatory activity than harmful antibacterial-negating effects. This remains to be determined in-vivo. The commensal strain Bacteroides thetaiotaomicron has been reported to restrict flagellin-mediated signalling also [19]. The responsible mechanism(s) has not been described, but it is possible that commensal surface structures engage with host cell receptors to modulate inflammatory responses $[18,46]$. The ability of $B$. infantis and $B$. thetaiotaomicron to restrain the signalling induced by flagellin and pathogenic bacteria may limit exaggerated inflammatory responses to the antigenic burden within the gut and contribute to the maintenance of mucosal homeostasis. Studies by us and others have shown that a variety of commensal bacteria including $B$. infantis and $L$. salivarius can suppress IL-8 secretion at baseline and from infected IECs [21-23]. The anti-inflammatory effects of these commensal bacteria have been shown to be mediated, at least in part, via NF$\kappa \mathrm{B}$ [23]. NF- $\kappa \mathrm{B}$ transcriptionally regulates both CCL20 and IL- $8[35,36]$ and a number of mechanisms by which some commensal bacteria antagonize NF- $\kappa \mathrm{B}$ have been described. These include degradation of the NF- $\mathrm{KB}$ inhibitor IкB- $\alpha$, or by the nuclear export of the p 65 subunit of $\mathrm{NF}-\kappa \mathrm{B}$ in a peroxisome proliferator-activated receptor $\gamma$ dependent manner $[19,20]$.

Our data shows that $M$. paratuberculosis can activate NF- $\mathrm{KB}$ and induce the secretion of IL- 8 and CCL20 from HT-29 human IECs. This would suggest that $M$. paratuberculosis may have a role in mediating mucosal damage in the gut. In ruminants and primates, M. paratuberculosis causes Johne's disease, a chronic granulomatous enteritis that is very similar to Crohn's disease in humans [47]. Crohn's disease is an immune-mediated inflammatory bowel dis- 
order that appears to be triggered by a complex interaction of environmental, genetic, and immunoregulatory factors [48]. The possibility that $M$. paratuberculosis infection may underlie Crohn's disease has been pursued inconclusively $[49,50]$, but few studies have investigated whether $M$. paratuberculosis can cause mucosal damage in the gut.

\section{Conclusion}

In conclusion, we have demonstrated that $B$. infantis can attenuate CCL20 secretion in HT-29 IECs; thereby modulating responses to limit inflammatory signals induced by flagellin and flagellated pathogenic bacteria. Furthermore, the data demonstrate that $M$. paratuberculosis activates immune responses in HT-29 human IECs. We speculate that $M$. paratuberculosis may mediate mucosal damage and that certain commensal bacteria can contribute to the maintenance of mucosal homeostasis by restraining exaggerated inflammatory response to the antigenic burden within the gut. Similar experiments on different human IEC lines and ex-vivo IECs would further validate our results. Future investigations are expected to improve our understanding of the mechanisms involved in the bacteria-intestinal cell interactions.

\section{Abbreviations}

CCL20: CC-chemokine ligand 20; CFU: colony forming units; DCs: dendritic cells; DMEM: Dulbecco's Modified Eagles medium; ELISA: enzyme-linked immunosorbent assay; FCS: fetal calf serum; IL: interleukin; IECs: intestinal epithelial cells; MRS: de Man Rogosa Sharpe; NF: nuclear factor; NOD/CARD: nucleotide-binding oligomerisation domain/caspase recruitment domain; TLR: toll-like receptor; TSA: tryptic soy agar.

\section{Authors' contributions}

SS carried out work involving mycobacteria, conceived the study and drafted the manuscript. AMOH carried out work with commenseal bacteria and Salmonella, conceived the study and drafted the manuscript. JR carried out work involving Clostridium. AF carried out immunoassays. JOM and SON were responsible for growing and validating mycobacteria. BS carried out work on commensal bacteria. LOM and FS participated in the design and coordination of the study and helped to draft the manuscript. All authors read and approved the final manuscript.

\section{Acknowledgements}

The authors' work is supported, in part, by Science Foundation Ireland in the form of a centre grant (Alimentary Pharmabiotic Centre), the Irish Health Research Board, the Higher Education Authority of Ireland, and the European Union.

\section{References}

I. Rakoff-Nahoum S, Paglino J, Eslami-Varzaneh F, Edberg S, Medzhitov $\mathrm{R}$ : Recognition of commensal microflora by toll-like recep- tors is required for intestinal homeostasis. Cell 2004, I I 8(2):229-24I.

2. Kagnoff MF, Eckmann L: Epithelial cells as sensors for microbial infection. Clin Invest 1997, 100(I):6-10.

3. Niess JH, Brand S, Gu X, Landsman L, Jung S, McCormick BA, Vyas JM, Boes M, Ploegh HL, Fox JG, Littman DR, Reinecker HC: CX3CRI-mediated dendritic cell access to the intestinal lumen and bacterial clearance. Science 2005, 307(5707):254-258.

4. Kelsall BL, Biron CA, Sharma O, Kaye PM: Dendritic cells at the host-pathogen interface. Nat Immunol 2002, 3(8):699-702.

5. Rescigno M, Urbano M, Valzasina B, Francolini M, Rotta G, Bonasio R, Granucci F, Kraehenbuhl JP, Ricciardi-Castagnoli P: Dendritic cells express tight junction proteins and penetrate gut epithelial monolayers to sample bacteria. Nat Immunol 200I, 2(4):36I-367.

6. Rescigno M: Dendritic cells and the complexity of microbial infection. Trends Microbiol 2002, 10(9):425-46I.

7. Kim CH: The greater chemotactic network for lymphocyte trafficking: chemokines and beyond. Curr Opin Hematol 2005, I 2(4):298-304.

8. Rossi D, Zlotnik A: The biology of chemokines and their receptors. Annu Rev Immunol 2000, I 8:2 1 7-242.

9. Schutyser E, Struyf S, Van Damme J: The CC chemokine CCL20 and its receptor CCR6. Cytokine Growth Factor Rev 2003, I 4(5):409-426.

10. Crane-Godreau MA, Wira CR: Effect of Escherichia coli and Lactobacillus rhamnosus on macrophage inflammatory protein 3 alpha, tumor necrosis factor alpha, and transforming growth factor beta release by polarized rat uterine epithelial cells in culture. Infect Immun 2004, 72(4): I866-1873.

II. Iwasaki A, Kelsall BL: Localization of distinct Peyer's patch dendritic cell subsets and their recruitment by chemokines macrophage inflammatory protein (MIP)-3alpha, MIP-3beta, and secondary lymphoid organ chemokine. J Exp Med 2000, 191(8): I38I-1394.

12. Cook DN, Prosser DM, Forster R, Zhang J, Kuklin NA, Abbondanzo SJ, Niu XD, Chen SC, Manfra DJ, Wiekowski MT, Sullivan LM, Smith SR, Greenberg HB, Narula SK, Lipp M, Lira SA: CCR6 mediates dendritic cell localization, lymphocyte homeostasis, and immune responses in mucosal tissue. Immunity 2000, I 2(5):495-503.

13. Dieu-Nosjean MC, Massacrier C, Homey B, Vanbervliet B, Pin JJ, Vicari A, Lebecque S, Dezutter-Dambuyant C, Schmitt D, Zlotnik A, Caux C: Macrophage inflammatory protein 3alpha is expressed at inflamed epithelial surfaces and is the most potent chemokine known in attracting Langerhans cell precursors. J Exp Med 2000, 192(5):705-718.

14. Fujiie S, Hieshima K, Izawa D, Nakayama T, Fujisawa R, Ohyanagi $H$, Yoshie $O:$ Proinflammatory cytokines induce liver and activation-regulated chemokine/macrophage inflammatory protein-3alpha/CCL20 in mucosal epithelial cells through NFkappaB. Int Immunol 200I, I 3(10): I 255-1263.

15. Izadpanah A, Dwinell MB, Eckmann L, Varki NM, Kagnoff MF: Regulated MIP-3alpha/CCL20 production by human intestinal epithelium: mechanism for modulating mucosal immunity. Am J Physiol Gastrointest Liver Physiol 200I, 280(4):G7 I0-7I9.

16. Sierro F, Dubois B, Coste A, Kaiserlian D, Kraehenbuhl JP, Sirard JC: Flagellin stimulation of intestinal epithelial cells triggers CCL20-mediated migration of dendritic cells. Proc Natl Acad Sci USA 200I, 98(24): I 3722-13727.

17. Gewirtz AT, Navas TA, Lyons L, Godowski PJ, Madara JL: Bacterial flagellin activates basolaterally expressed TLR5 to induce epithelial proinflammatory gene expression. J Immunol 200I, 167:1882-1885.

18. Coyne MJ, Reinap B, Lee MM, Comstock LE: Human symbionts use a host-like pathway for surface fucosylation. Science 2005 , 307(57 I6): I778-178I.

19. Kelly D, Campbell JI, King TP, Grant G, Jansson EA, Coutts AG, Pettersson S, Conway S: Commensal anaerobic gut bacteria attenuate inflammation by regulating nuclear-cytoplasmic shuttling of PPAR-gamma and RelA. Nat Immunol 2004, 5(1): 104-112.

20. Neish AS, Gewirtz AT, Zeng H, Young AN, Hobert ME, Karmali V, Rao AS, Madara JL: Prokaryotic regulation of epithelial 
responses by inhibition of IkappaB-alpha ubiquitination. Science 2000, 289(5484): I560-I563.

21. Otte JM, Podolsky DK: Functional modulation of enterocytes by gram-positive and gram-negative microorganisms. Am J Physiol Gastrointest Liver Physiol 2004, 286(4):G6| 3-626.

22. Ma $D$, Forsythe $P$, Bienenstock J: Live Lactobacillus reuteri is essential for the inhibitory effect on tumor necrosis factor alpha-induced interleukin-8 expression. Infect Immun 2004, 72(9):5308-53।4.

23. O'Hara AM, O'Regan P, Fanning A, O'Mahony C, Macsharry J, Lyons $A$, Bienenstock J, O'Mahony L, Shanahan F: Functional modulation of human intestinal epithelial cell responses by Bifidobacterium infantis and Lactobacillus salivarius. Immunology 2006, I I 8:202-2I5.

24. Dunne C, O'Mahony L, Murphy L, Thornton G, Morrissey D, O'HalIoran S, Feeney M, Flynn S, Fitzgerald G, Daly C, Kiely B, O'Sullivan GC, Shanahan F, Collins JK: In vitro selection criteria for probiotic bacteria of human origin: correlation with in vivo findings. Am J Clin Nutr 200I, 73(2 Suppl):386S-392S.

25. Dunne C, Murphy L, Flynn S, O'Mahony L, O'Halloran S, Feeney M, Morrissey D, Thornton G, Fitzgerald G, Daly C, Kiely B, Quigley EM, O'Sullivan GC, Shanahan F, Collins JK: Probiotics: from myth to reality. Demonstration of functionality in animal models of disease and in human clinical trials. Antonie Van Leeuwenhoek 1999, 76(1-4):279-292.

26. O'Mahony L, McCarthy J, Kelly P, Hurley G, Luo F, Chen K, O'Sullivan GC, Kiely B, Collins JK, Shanahan F, Quigley EM: Lactobacillus and bifidobacterium in irritable bowel syndrome: symptom responses and relationship to cytokine profiles. Gastroenterology 2005, I 28(3):54I-55I.

27. McCarthy J, O'Mahony L, O'Callaghan L, Sheil B, Vaughan EE, Fitzsimons N, Fitzgibbon J, O'Sullivan GC, Kiely B, Collins JK, Shanahan F: Double blind, placebo controlled trial of two probiotic strains in interleukin 10 knockout mice and mechanistic link with cytokine balance. Gut 2003, 52(7):975-980.

28. Bartlett JG: Clinical practice. Antibiotic-associated diarrhea. N Engl J Med 2002, 346(5):334-339.

29. Poxton IR, McCoubrey J, Blair G: The pathogenicity of Clostridium difficile. Clin Microbiol Infect 200I, 7(8):42I-427.

30. Savidge TC, Pan WH, Newman P, O'Brien M, Anton PM, Pothoulakis C: Clostridium difficile toxin $B$ is an inflammatory enterotoxin in human intestine. Gastroenterology 2003, I 25(2):4|3-420.

31. Gupta $S$, Chatterji D: Stress responses in mycobacteria. IUBMB Life 2005, 57(3): 149-159.

32. Mack DR, Ahrne S, Hyde L, Wei S, Hollingsworth MA: Extracellular MUC3 mucin secretion follows adherence of Lactobacillus strains to intestinal epithelial cells in vitro. Gut 2003, 52(6):827-833.

33. Haller D, Holt L, Parlesak A, Zanga J, Bauerlein A, Sartor RB, Jobin C: Differential effect of immune cells on non-pathogenic Gramnegative bacteriainduced nuclear factor-kappaB activation and pro-inflammatory gene expression in intestinal epithelial cells. Immunology 2004, I I 2(2):3 I0-320.

34. Crowe SE, Alvarez L, Dytoc M, Hunt RH, Muller M, Sherman P, Patel $J$, Jin $Y$, Ernst PB: Expression of interleukin 8 and CD54 by human gastric epithelium after Helicobacter pylori infection in vitro. Gastroenterology 1995, 108(1):65-74.

35. Jobin C, Sartor RB: The I kappa B/NF-kappa B system: a key determinant of mucosalinflammation and protection. $\mathrm{Am} J$ Physiol Cell Physiol 2000, 278(3):C45I-462.

36. Sugita $S$, Kohno T, Yamamoto K, Imaizumi $Y$, Nakajima $H$, Ishimaru $T$, Matsuyama T: Induction of macrophage-inflammatory protein-3alpha gene expression by TNF-dependent NF-kappaB activation. J Immunol 2002, I68(II):562I-5628.

37. Canny G, Drudy D, Macmathuna P, O'Farrelly C, Baird AW: Toxigenic $C$. difficile induced inflammatory marker expression by human intestinal epithelial cells is asymmetrical. Life Sci 2006, 78(9):920-925.

38. Bambou JC, Giraud A, Menard S, Begue B, Rakotobe S, Heyman M, Taddei F, Cerf-Bensussan N, Gaboriau-Routhiau V: In vitro and ex vivo activation of the TLR5 signaling pathway in intestinal epithelial cells by a commensal Escherichia coli strain. J Biol Chem 2004, 279(4I):42984-42992.

39. Sirard JC, Didierlaurent A, Cayet D, Sierro F, Rumbo M: Toll-like receptor 5- and lymphotoxin beta receptor-dependent epithelial $\mathbf{C c l} 20$ expression involves the same NF-kappaB bind- ing site but distinct NF-kappaB pathways and dynamics. Biochim Biophys Acta 2000, I 789(5):386-394.

40. Lillehoj EP, Kim H, Chun EY, Kim KC: Pseudomonas aeruginosa stimulates phosphorylation of the Epithelial Membrane Glycoprotein Mucl and Activates MAP Kinase. Am J Physiol Lung Cell Mol Physiol 2004, 287(4):L809-L8I5.

4I. Tallant T, Deb A, Kar N, Lupica J, de Veer MJ, DiDonato JA: Flagellin acting via TLR5 is the major activator of key signaling pathways leading to NF-kappa B and proinflammatory gene program activation in intestinal epithelial cells. $B M C$ Microbiol 2004, 4:33.

42. Kwon JH, Keates S, Bassani L, Mayer LF, Keates AC: Colonic epithelial cells are a major site of macrophage inflammatory protein 3alpha (MIP-3alpha) production in normal colon and inflammatory bowel disease. Gut 2002, 5 I (6):8I 8-826.

43. Veckman V, Miettinen M, Matikainen S, Lande R, Giacomini E, Coccia $\mathrm{EM}$, Julkunen I: Lactobacilli and streptococci induce inflammatory chemokine production in human macrophages that stimulates ThI cell chemotaxis. J Leukoc Biol 2003, 74(3):395-402.

44. Toki S, Kagaya S, Shinohara M, Wakiguchi H, Matsumoto T, Takahata Y, Morimatsu F, Saito H, Matsumoto K: Lactobacillus rhamnosus GG and Lactobacillus casei suppress Escherichia coliinduced chemokine expression in intestinal epithelial cells. Int Arch Allergy Immunol 2009, I 48(I):45-58.

45. Begue B, Dumant C, Bambou JC, Beaulieu JF, Chamaillard M, Hugot JP, Goulet O, Schmitz J, Philpott DJ, Cerf-Bensussan N, Ruemmele FM, et al: Microbial induction of CARDI 5 expression in intestinal epithelial cells via toll-like receptor 5 triggers an antibacterial response loop. Journal of cellular Physiology 2006, 209(2):24I-252.

46. Granato D, Bergonzelli GE, Pridmore RD, Marvin L, Rouvet M, Corthesy- Theulaz IE: Cell surface-associated elongation factor Tu mediates the attachment of Lactobacillus johnsonii NCC533 (Lal) to human intestinal cells and mucins. Infect Immun 2004, 72(4):2160-2169.

47. Chacon O, Bermudez LE, Barletta RG: Johne's disease, inflammatory bowel disease, and Mycobacterium paratuberculosis. Annu Rev Microbiol 2004, 58:329-363.

48. O'Hara AM, Shanahan F: Gut microbiota: mining for therapeutic potential. Clin Gastroenterol Hepatol 2007, 5(3):274-284.

49. Sartor RB: Does Mycobacterium avium subspecies paratuberculosis cause Crohn's disease? Gut 2005, 54(7):896-898.

50. Shanahan F, O'Mahony J: The mycobacteria story in Crohn's disease. Am J Gastroenterol 2005, I 00(7): I537-I538.

\section{Publish with Biomed Central and every scientist can read your work free of charge}

"BioMed Central will be the most significant development for disseminating the results of biomedical research in our lifetime. "

Sir Paul Nurse, Cancer Research UK

Your research papers will be:

- available free of charge to the entire biomedical community

- peer reviewed and published immediately upon acceptance

- cited in PubMed and archived on PubMed Central

- yours - you keep the copyright
BioMedcentral 